Brit. F. vener. Dis. (1971) 47, 413

\title{
Bactericidal activity of antimicrobial agents for treponemes
}

\author{
I. J. ABRAMSON AND R. M. SMIBERT * \\ Anaerobe Laboratory, Virginia Polytechnic Institute and State University, Blacksburg, Virginia 24060, U.S.A.
}

Bactericidal studies of antibiotics on treponemes have been limited to a small group of organisms and to a limited number of antimicrobial agents.

Eagle and Musselman (1944) determined the sensitivity in vitro of the non-virulent Reiter treponeme to penicillin G. Penicillin concentrations of between 0.1 and 0.25 units $/ \mathrm{ml}$. medium killed 90 to 99 per cent. of the spirochaetes in 8 to $12 \mathrm{hrs}$. Penicillin was equally active against a cultivable mouth treponeme and the Nichols, Noguchi, and Kazan treponemes. Eagle, Musselman, and Fleischman (1948) tested the Reiter treponeme for bactericidal sensitivity to bacitracin. They reported that 0.025 units bacitracin/ $\mathrm{ml}$. medium were treponemicidal within 24 to $48 \mathrm{hrs}$. Fitzgerald and Hampp (1952) investigated the treponemicidal activity of several antibiotics against three strains of Treponema vincentii and three strains of an oral treponeme. Subculture into antibiotic-free medium was used to distinguish inhibitory from bactericidal concentrations. Treponemicidal concentrations for penicillin, aureomycin, chloramphenicol, and streptomycin at 7 days were two to four times those of the inhibitory concentration. Hampp and Fitzgerald (1959) examined three strains of $T$. vincentii, three oral treponemes, and three strains of Borrelia buccalis. Absence of motility and the presence of bizarre forms were considered to be evidence of spirochaetal death. Antibiotics considered to be treponemicidal were penicillin, oleandomycin, novobiocin, erythromycin, and vancomycin.

The purpose of this study was to determine the bactericidal concentrations of a large number of antimicrobial agents using representative strains of the cultivable species or groups of treponemes. In addition, investigations were made into the occurrance of spontaneous and penicillin-induced mutants.

\section{Material and Methods}

Pre-reduced, anaerobic media were prepared as described in the 'Outline of Clinical Methods in Anaerobic Bacteriology' (Anaerobe Laboratory, 1970). The composition

Received for publication May 28, 1971

$\star$ Requests for reprints of media, inoculation techniques, preservation of cultures, incubation temperatures, and the strains of treponemes studied were as described in a previous communication (Abramson and Smibert, 1971).

ANTIMICROBIAL AGENTS

Antibiotics and chemicals were diluted to final concentrations of $0.01,0 \cdot 1,1,10,100,500$, and $1,000 \mu \mathrm{g}$. or units $/ \mathrm{ml}$. in $7.5 \mathrm{ml}$. culture medium.

BACTERICIDAL CONCENTRATIONS

These were considered to be the lowest concentrations in the dilution series at which subculture into normak medium produced no visible growth in 14 days. After 30 days incubation $0.5 \mathrm{ml}$. amounts of both test and control cultures were subcultured to normal medium to determine whether or not any viable organisms remained. The subcultures were incubated for 3 days and transfers $(0.5$ ml.) from them were again made into normal medium if no growth had appeared on the 3 rd day. All cultures were incubated for 14 days before being discarded as negative.

\section{PENICILLIN-RESISTANT MUTANTS}

Demonstration of spontaneously occurring mutants resistant to penicillin was based on the fluctuation analysis described by Luria and Delbrück (1943) and by Demerec (1948). A 24-hr culture of the Reiter strain of $T$. phagedenis was diluted to contain 1,000 cells $/ \mathrm{ml} .0 \cdot 1 \mathrm{ml}$. of this was pipetted into each of eight tubes containing $2 \mathrm{ml}$. of PYG-serum medium and incubated for $24 \mathrm{hrs}$. Direct microscopic counts were made in a Petroff Hausser Chamber.

$1 \mathrm{ml}$. amounts of each culture were diluted 10 -fold from $10^{-1}$ to $10^{-8}$ in PYGS medium containing 100 units $/ \mathrm{ml}$. penicillin $G$. This was repeated until all of the cultures were used so that the entire population of cells in the test culture could be tested for spontaneously occurring penicillin-resistant mutants. A sample of the original 24-hr culture was also diluted in duplicate from $10^{-1}$ to $10^{-8}$ in PYGS medium containing 100 units $/ \mathrm{ml}$. penicillin G. In addition, a sample of test culture was diluted 10 -fold from $10^{-1}$ to $10^{-8}$ in normal PYGS medium. All cultures were incubated at $37^{\circ} \mathrm{C}$. for 14 days and observed daily for growth. When growth occurred, the culture was compared with the wild strain for differences in sensitivity to penicillin $\mathrm{G}$.

In an attempt to induce penicillin-resistant mutants, 
$0.1 \mathrm{ml}$. of a 24-hr culture of the Reiter treponeme was inoculated into $2 \mathrm{ml}$. PYGS medium containing $0 \cdot 1$ unit/ $\mathrm{ml}$. potassium penicillin G. Samples $(0.1 \mathrm{ml}$.) of the culture were transferred into PYGS medium containing 10 per cent. sucrose both with and without 1 unit $/ \mathrm{ml}$. penicillin and incubated for 7 days. Subcultures $(0.1 \mathrm{ml}$.) were made weekly into $2 \mathrm{ml}$. PYGS-10 per cent. sucrose medium containing $1 \mathrm{unit} / \mathrm{ml}$. penicillin $\mathrm{G}$ and into normal medium. Treponemes were subcultured once each week in the same penicillin concentration for four serial transfers. Cells from the fourth transfer were used to inoculate medium containing 5 and then 10 units $/ \mathrm{ml}$. penicillin G. All cultures were incubated for 1 month, observed daily for growth, and examined with a darkfield microscope each week. Cultures growing in penicillin medium were compared with the wild strain for differences in penicillin sensitivity.

Tubes of PYGS-10 per cent. sucrose medium containing $10,50,100,200,300,500$, and $1,000 \mu \mathrm{g} . / \mathrm{ml}$. ampicillin and normal medium were inoculated with $0.3 \mathrm{ml}$. of a 24-hr culture of the Reiter treponeme and incubated for 4 days. $0.3 \mathrm{ml}$. of culture from each tube of medium were transferred into PYGS-10 per cent. sucrose medium containing the same ampicillin concentration as that in which they were being incubated. Four passages were made in a period of 3 weeks, and a final passage was made into ampicillin-free PYGS-10 per cent. sucrose medium. Observations for growth were made daily. When growth occurred, the cultures were compared with the wild strain for differences in ampicillin sensitivity.

\section{Results}

Tables I to $\mathrm{V}$ show the concentrations of the various antimicrobial agents that were bactericidal to the treponemes studied. There was no antimicrobial agent to which every strain was sensitive. Many strains were apparently sensitive to cephalothin (Table I) and most were resistant to the penicillins. Table II shows that most strains were apparently sensitive to vancomycin, bacitracin, erythromycin, tylosin, and lincomycin, while about half of them were resistant to novobiocin. They had the greatest sensitivity to erythromycin.

In Table III, most of the serum-requiring and human oral (HO) isolates were apparently slightly sensitive to the tetracyclines except chlortetracycline.

The pig faecal (PF) strains were resistant to tetracyclines. Most isolates were resistant to chloramphenical. Most strains were resistant to the antimicrobial agents listed in Tables IV and V. Two of the three strains tested were sensitive to gentamicin. All treponeme strains were resistant to cycloserine ( 500 to $>1,000 \mu \mathrm{g} . / \mathrm{ml}$.), polymyxin B sulphate $(1,000$ to $>1,000 \mu \mathrm{g} . / \mathrm{ml}$.), furazolidone $(100$ to $>1,000$ $\mu \mathrm{g} . / \mathrm{ml}$.), nalidixic acid $(1,000$ to $>1,000 \mu \mathrm{g} . / \mathrm{ml}$.), methenamine mandelate $(500$ to $>1,000 \mu \mathrm{g} . / \mathrm{ml}$.), lysozyme ( $>1,000 \mu \mathrm{g} . / \mathrm{ml})$, lysostaphin $(>1,000$ $\mu \mathrm{g} . / \mathrm{ml}$.), sulphathiazole $(1,000$ to $>1,000 \mu \mathrm{g} . / \mathrm{ml}$.) sulphaquinoxaline $(1,000$ to $>1,000 \mu \mathrm{g} . / \mathrm{ml}$.), sulphadiazine $(1,000$ to $>1,000 \mu \mathrm{g} . / \mathrm{ml}$.), succinyl sulphathiazole $(1,000$ to $>1,000 \mu \mathrm{g} . / \mathrm{ml}$.), 5-amino-uracilo $\left(>1,000 \mu \mathrm{g} . / \mathrm{ml}\right.$.), 5-fluor-ouracil (100 to $>1,000^{\circ}$ $\mu \mathrm{g} . / \mathrm{ml}$.), 5-iodouracil $(1,000$ to $>1,000 \mu \mathrm{g} . / \mathrm{ml}$.), thallium acetate $(100$ to $500 \mu \mathrm{g} . / \mathrm{ml}$.), azocarmine (100 to $>1,000 \mu \mathrm{g} . / \mathrm{ml}$.), indigocarmine $(1,000$ to $>1,000 \mu \mathrm{g} . / \mathrm{ml}$.), and toluidine blue 0 (500 to $>1,000 \mu \mathrm{g} . / \mathrm{ml}$.).

TABLE I Bactericidal concentrations of the penicillins

\begin{tabular}{|c|c|c|c|c|c|c|c|c|}
\hline & & \multicolumn{7}{|c|}{ Bactericidal concentrations of antimicrobial agents } \\
\hline \multicolumn{2}{|l|}{ Treponeme strains } & $\begin{array}{l}\text { Pen d } \\
\text { (units/ml.) }\end{array}$ & $\begin{array}{l}A m p^{e} \\
(\mu g . / m l .)\end{array}$ & $\begin{array}{l}\text { Nafi } \\
(\mu g . / m l .)\end{array}$ & $\begin{array}{l}\text { Oxg } \\
(\mu g . / m l .)\end{array}$ & $\begin{array}{l}\text { Clox h } \\
(\mu g . / m l .)\end{array}$ & $\begin{array}{l}\text { KPMP } \\
\left(\mu g . / m^{1} .\right)\end{array}$ & $\begin{array}{l}\text { Ceph } \\
(\mu g . / m l .)\end{array}$ \\
\hline $\begin{array}{l}\text { Reiter }^{\mathrm{a}} \\
\text { Kazan }^{\mathrm{a}} \\
\text { T. refringens } \\
\text { Calligyrum } \\
\text { Nichols }^{\mathrm{b}} \\
\text { Microdentium FMc }^{\mathrm{c}} \\
\text { Ambiguum }^{\mathrm{c}} \\
\mathrm{T}-32-\mathrm{A}^{\mathrm{c}} \\
T . \text { vincentii }^{\mathrm{N}} \mathrm{N}-9\end{array}$ & & $\begin{array}{c}100-500^{\star} \\
>1,000 \\
100 \\
10 \\
100 \\
10 \\
10 \\
100 \\
0 \cdot 1\end{array}$ & $\begin{array}{r}500 \\
500 \\
10 \\
10 \\
100 \\
100 \\
10 \\
100 \\
1\end{array}$ & $\begin{array}{r}100 \\
100 \\
10 \\
10 \\
10 \\
500 \\
10 \\
100 \\
1\end{array}$ & $\begin{array}{r}100 \\
500 \\
10 \\
100 \\
500 \\
100 \\
10 \\
100 \\
1\end{array}$ & $\begin{array}{r}100 \\
500 \\
1 \\
100 \\
100 \\
100 \\
10 \\
100 \\
0 \cdot 1\end{array}$ & $\begin{array}{r}100 \\
>1,000 \\
500 \\
10 \\
100 \\
100 \\
10 \\
100 \\
1\end{array}$ & $\begin{array}{c}100 \\
100 \\
1 \\
0 \cdot 1 \\
1 \\
1 \\
1 \\
1 \\
0 \cdot 1\end{array}$ \\
\hline Human oral cavity & $\begin{array}{lr}\text { HO } & 5 \\
\text { HO } & 18 \\
\text { HO } & 27\end{array}$ & $\begin{array}{r}100 \\
>1,000 \\
>1,000\end{array}$ & $\begin{array}{r}500 \\
>1,000 \\
>1,000\end{array}$ & $\begin{array}{r}500 \\
>1,000 \\
>1,000\end{array}$ & $\begin{array}{r}500 \\
>1,000 \\
>1,000\end{array}$ & $\begin{array}{r}500 \\
>1,000 \\
>1,000\end{array}$ & $\begin{array}{r}500 \\
>1,000 \\
>1,000\end{array}$ & $\begin{array}{l}0 \cdot 1 \\
10 \\
10\end{array}$ \\
\hline Pig faeces & $\begin{array}{l}\text { PF } 23 \\
\text { PF } 31 \\
\text { PF } 39 \\
\text { PF } 28 \\
\text { PF 44 }\end{array}$ & $\begin{array}{l}500 \\
100 \\
500 \\
500 \\
500\end{array}$ & $\begin{array}{r}10 \\
500 \\
500 \\
100 \\
1,000\end{array}$ & $\begin{array}{r}10 \\
100 \\
10 \\
10 \\
10\end{array}$ & $\begin{array}{r}1,000 \\
100 \\
500 \\
1,000 \\
500\end{array}$ & $\begin{array}{r}500 \\
500 \\
500 \\
10 \\
500\end{array}$ & $\begin{array}{l}500 \\
500 \\
500 \\
500 \\
500\end{array}$ & $\begin{array}{r}1 \\
10 \\
1 \\
1 \\
10\end{array}$ \\
\hline
\end{tabular}

- Treponema phagedenis, ${ }^{\mathrm{b}} \mathrm{T}$. refringens, ${ }^{\mathrm{c}} \mathrm{T}$. denticola, ${ }^{\mathrm{d}}$ penicillin $\mathrm{G}$, eampicillin, ${ }^{\mathrm{I}}$ afcillin, ${ }^{\mathrm{B}} \mathrm{oxacillin}$, ${ }^{\mathrm{h}} \mathrm{cloxacillin},{ }^{\mathrm{I}} \mathrm{K}$ phenoxymethyl penicillin jcephalothin

*Results with Reiter treponeme varied between 100 and 500 units $/ \mathrm{ml}$. in different tests 
Spontaneous mutants of the Reiter strain of $T$. phagedenis resistant to penicillin G were not found. Growth was not observed in any test dilution in medium with 100 units $/ \mathrm{ml}$. penicillin, nor were treponemes observed in any culture by darkfield microscopy. Mutants resistant to penicillin G were not isolated as a result of the growth of cultures in step-wise transfers in PYGS-10 per cent. sucrose medium containing $0 \cdot 1,1,5$, or 10 units $/ \mathrm{ml}$. penicillin G (Table VI).

Table VII shows that ampicillin-resistant mutants of the Reiter strain of $T$. phagedenis were not found and indicates the inhibitory effects that various concentrations of ampicillin had on the organism. By darkfield microscopy, normal motile treponemes were observed as the predominant cell population in PYGS-10 per cent. sucrose medium containing 10 to $100 \mu \mathrm{g} . / \mathrm{ml}$. ampicillin; while coccoid bodies, granules, long forms, and motile treponemes were observed in cultures in PYGS-10 per cent. sucrose medium containing 200 to $1,000 \mu \mathrm{g}$./ml. ampicillin. The numbers of coccoid bodies increased and the

TABLE II Bactericidal concentrations of macrolides and other antibiotics

\begin{tabular}{|c|c|c|c|c|c|c|}
\hline \multirow[b]{2}{*}{ Treponeme strains } & \multicolumn{6}{|c|}{ Bactericidal concentrations of antimicrobial agents } \\
\hline & $\begin{array}{l}\text { Novod } \\
(\mu g \cdot / m l .)\end{array}$ & $\begin{array}{l}\text { Vanco } \\
(\mu g . / \mathrm{ml} .)\end{array}$ & $\begin{array}{l}\text { Bac } \\
\text { (units/ml.) }\end{array}$ & $\begin{array}{l}\text { Eryg } \\
(\mu g . / m l .)\end{array}$ & $\begin{array}{l}\text { Tyloh } \\
(\mu g . / m l .)\end{array}$ & $\begin{array}{l}\operatorname{Linco}^{1} \\
(\mu g . / m l .)\end{array}$ \\
\hline Reiter $^{\mathbf{a}}$ & 100 & 10 & 10 & 500 & 100 & 100 \\
\hline Kazan $^{\mathbf{a}}$ & 100 & 10 & 10 & 10 & 10 & 100 \\
\hline$T$. refringens & 500 & 1 & 0.1 & $0 \cdot 1$ & 10 & 10 \\
\hline Calligyrumb & 500 & 1 & $0 \cdot 1$ & 1 & 10 & 10 \\
\hline Nichols ${ }^{\mathrm{b}}$ & 500 & $0 \cdot 1$ & $0 \cdot 1$ & $0 \cdot 1$ & 1 & 1 \\
\hline Microdentium FMc & 100 & 1 & 10 & 1 & 100 & 10 \\
\hline Ambiguum ${ }^{c}$ & 100 & 10 & 10 & $0 \cdot 1$ & 10 & 100 \\
\hline$T-32-A^{c}$ & 10 & 10 & 1 & $0 \cdot 1$ & 10 & 10 \\
\hline$T$. vincentii $\mathrm{N}-9$ & 1 & 1 & $0 \cdot 1$ & $0 \cdot 1$ & 1 & 10 \\
\hline HO 5 & 100 & 10 & 1 & $0 \cdot 1$ & 1 & 100 \\
\hline HO 18 & 500 & 100 & 1 & $0 \cdot 1$ & 10 & 100 \\
\hline HO 27 & 500 & 100 & 1 & $0 \cdot 1$ & 10 & 100 \\
\hline PF 23 & 10 & 100 & 10 & 10 & 10 & 10 \\
\hline PF 31 & 10 & 500 & 10 & 1 & 10 & 10 \\
\hline PF 39 & 10 & 500 & 100 & $0 \cdot 1$ & 10 & 10 \\
\hline PF 28 & 10 & 100 & 10 & 0.1 & 10 & 10 \\
\hline PF 44 & 10 & 500 & 10 & 1 & 100 & 10 \\
\hline
\end{tabular}

${ }^{\mathrm{a}}$ Treponema phagedenis, ${ }^{\mathrm{b}} \mathrm{T}$. refringens, ${ }^{\mathrm{c}} \mathrm{T}$. denticola, ${ }^{\mathrm{d}}$ novobiocin, ${ }^{\mathrm{e}} \mathrm{vancomycin},{ }^{\mathrm{t}}$ bacitracin, $\mathrm{g}$ erythromycin, ${ }^{\mathrm{h}}$ tylosin, ${ }^{\mathrm{i} l i n c o m y c i n}$

TABLE II I Bactericidal concentrations of tetracyclines and chloramphenicol

\begin{tabular}{|c|c|c|c|c|c|c|c|}
\hline \multirow[b]{2}{*}{ Treponeme strains } & \multicolumn{7}{|c|}{ Bactericidal concentrations of antimicrobial agents } \\
\hline & $\begin{array}{l}T e t^{\mathrm{d}} \\
(\mu \mathrm{g} \cdot / \mathrm{ml} .)\end{array}$ & $\begin{array}{l}\text { Chlortet } \\
(\mu g . / m l .)\end{array}$ & $\begin{array}{l}\text { Oxytet }{ }^{p} \\
(\mu g . / m l .)\end{array}$ & $\begin{array}{l}\text { Dmethch } \\
(\mu g . / m l .)\end{array}$ & $\begin{array}{l}\operatorname{Doxy} y^{\mathrm{h}} \\
(\mu \mathrm{g} . / \mathrm{ml} .)\end{array}$ & $\begin{array}{l}\text { Methac } \\
(\mu g . / m l .)\end{array}$ & $\begin{array}{l}\text { Chloram }^{\text {S }} \\
(\mu \mathrm{g} . / \mathrm{ml} .)\end{array}$ \\
\hline Reiter $^{\mathbf{2}}$ & 10 & 100 & 10 & 1 & 10 & 10 & 500 \\
\hline Kazan $^{\mathrm{a}}$ & 10 & 100 & 100 & 10 & 10 & 10 & 1,000 \\
\hline T. refringens & 1 & 100 & 10 & 1 & 1 & 1 & 100 \\
\hline Calligyrum ${ }^{\mathrm{b}}$ & 1 & 10 & 10 & 1 & 1 & 1 & 100 \\
\hline Nichols ${ }^{b}$ & 1 & 10 & 10 & 1 & 10 & 1 & 500 \\
\hline Microdentium FMc & 10 & 100 & 10 & 1 & 1 & 1 & 100 \\
\hline Ambiguum ${ }^{c}$ & 10 & 100 & 10 & 1 & 1 & 1 & 100 \\
\hline$T-32-A^{c}$ & 1 & 100 & 1 & 1 & 1 & 1 & 100 \\
\hline$T$. vincentii $\mathrm{N}-9$ & 10 & 100 & 10 & 1 & 1 & 1 & 100 \\
\hline HO 5 & 10 & 100 & 10 & 10 & 10 & 10 & 100 \\
\hline HO 18 & 10 & 100 & 10 & 10 & 10 & 1 & 100 \\
\hline HO 27 & 10 & 100 & 10 & 10 & 10 & 10 & 500 \\
\hline PF 23 & 500 & 1,000 & 500 & 100 & 100 & 500 & 100 \\
\hline PF 31 & 100 & 100 & 100 & 100 & 100 & 100 & 10 \\
\hline PF 39 & 500 & 500 & 100 & 100 & 500 & 100 & 100 \\
\hline PF 28 & 100 & 500 & 100 & 100 & 500 & 500 & 10 \\
\hline PF 44 & 500 & 500 & 500 & 100 & 500 & 500 & 100 \\
\hline
\end{tabular}

${ }^{\mathrm{a}}$ Treponema phagedenis, ${ }^{\mathrm{b}} T$. refringens, ${ }^{\mathrm{c}} T$. denticola, dtetracycline, echlortetracycline, 'oxytetracycline, ${ }^{\mathrm{s}}$ demethylchlortetracycline, ${ }^{\mathrm{h}}$ doxycycline 'methacycline, 'chloramphenicol 
TABLE IV Bactericidal concentrations of aminoglycoside and peptide antibiotics

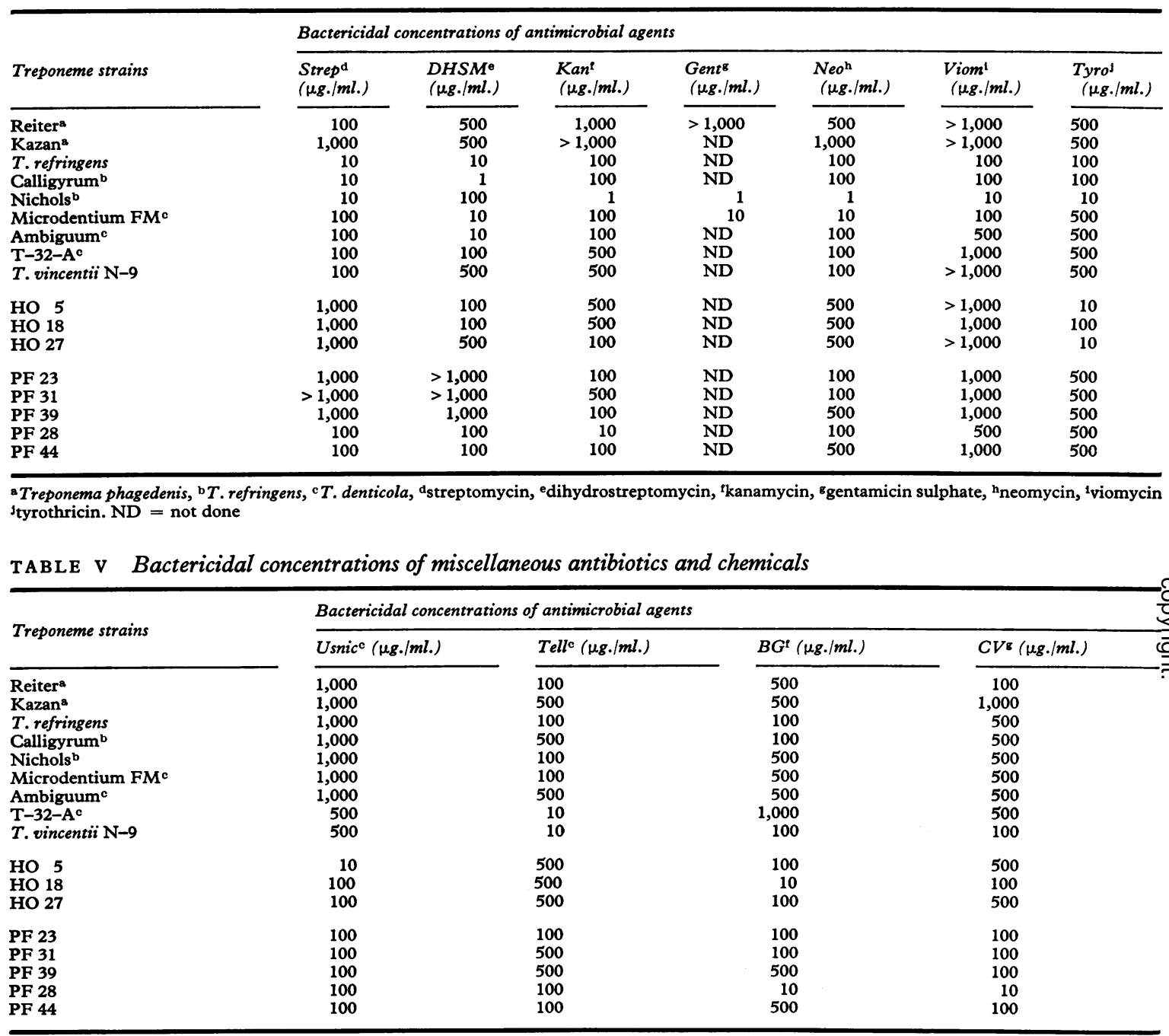

${ }^{\mathrm{a}}$ Treponema phagedenis, ${ }^{\mathrm{b}} \mathrm{T}$. refringens, ${ }^{\mathrm{c}} \mathrm{T}$. denticola, ${ }^{\mathrm{d}}$ usnic acid, ${ }^{\mathrm{e}} \mathrm{K}$ tellurite, ${ }^{\mathrm{b}} \mathrm{b}$ rilliant green, ${ }_{\mathrm{g}} \mathrm{crystal}$ violet

TABLE VI Growth of the Reiter strain of T. phagedenis in step-wise concentrations of potassium penicillin $G$ in PYG-serum-10 per cent. sucrose medium

\begin{tabular}{|c|c|c|c|c|}
\hline \multirow[b]{2}{*}{ Concentration (units/ml.) } & \multirow[b]{2}{*}{ No. of transfers } & \multicolumn{3}{|c|}{ Days until growth of treponemes } \\
\hline & & Control* & $\begin{array}{l}\text { Inoculum in penicillin } \\
\text { containing medium }\end{array}$ & $\begin{array}{l}\text { Bactericidal concentration } \\
\text { (units/ml.) }\end{array}$ \\
\hline $\begin{array}{l}0 \\
0 \cdot 1 \\
1 \\
5 \\
10\end{array}$ & $\begin{array}{l}4 \\
1 \\
4 \\
4 \\
4\end{array}$ & $\begin{array}{r}1 \\
3 \\
6 \\
11 \\
22\end{array}$ & $\begin{array}{r}3 \\
3 \\
9 \\
15 \\
25\end{array}$ & $\begin{array}{l}100^{\star \star} \\
100 \\
100 \\
100 \\
100\end{array}$ \\
\hline
\end{tabular}

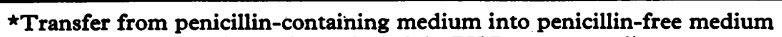

$\star \star$ Varied from 100 units to 500 units/ml. in PYG-serum medium 
TABLE VII Days until treponemal growth of the Reiter strain of $\mathrm{T}$. phagedenis in transfers in PYG-serum-10 per cent. sucrose medium containing various concentrations of ampicillin

\begin{tabular}{|c|c|c|c|c|c|c|c|c|c|}
\hline \multirow{2}{*}{ No. of transfers in ampicillin } & \multicolumn{9}{|c|}{ Concentration of ampicillin ( $\mu \mathrm{g} . / \mathrm{ml})}$. \\
\hline & 0 & 10 & 50 & 100 & 200 & 300 & 400 & 500 & 1,000 \\
\hline $\begin{array}{l}1 \\
2 \\
3 \\
4 \\
5\end{array}$ & $\begin{array}{l}1 \\
1 \\
2 \\
2 \\
2\end{array}$ & $\begin{array}{r}3 \\
3 \\
4 \\
3 \\
12\end{array}$ & $\begin{array}{r}3 \\
3 \\
5 \\
7 \\
12\end{array}$ & $\begin{array}{r}3 \\
4 \\
7 \\
10 \\
15\end{array}$ & $\begin{array}{r}7 \\
8 \\
9 \\
11 \\
15\end{array}$ & $\begin{array}{l}13 \\
13 \\
10 \\
10 \\
14\end{array}$ & $\begin{array}{l}13 \\
10 \\
15 \\
10 \\
18\end{array}$ & $\begin{array}{r}9 \\
12 \\
20 \\
20 \\
18\end{array}$ & $\begin{array}{l}21 \\
- \\
-\end{array}$ \\
\hline Treponemicidal conc. ${ }^{\star}$ & 100 & 100 & 100 & 100 & 100 & 100 & 100 & 100 & 100 \\
\hline
\end{tabular}

- = no growth in 30 days

* = Treponemicidal concentration in PYG-serum medium in 14 days

number of treponemes decreased with each successive transfer. The treponemicidal concentrations of ampicillin for these cultures were the same as that for the wild strain.

\section{Discussion}

Abramson and Smibert (1971) suggested that treponemes should be considered to be sensitive if inhibited or killed by $10 \mu \mathrm{g}$. (units) or less of an antimicrobial agent $/ \mathrm{ml}$. of medium. Most treponemes regarded as sensitive in this study were killed by 1 $\mu \mathrm{g} . / \mathrm{ml}$. or less of antibiotics. Judged by these criteria, none of the antimicrobial agents studied was bactericidal to every treponemal strain. Most treponemes were sensitive to cephalothin, vancomycin, bacitracin, erythromycin, tylosin, lincomycin, and tetracyclines.

Most strains were resistant to the penicillins, chlortetracycline, chloramphenicol, streptomycin, dihydrostreptomycin, kanamycin, neomycin, viomycin, tyrothricin, usnic acid, potassium tellurite, brilliant green, and crystal violet. Approximately 50 per cent. of them were resistant to novobiocin. The penicillins were generally bactericidal to treponemes at much higher concentrations than the growth inhibitory level. For example, the Reiter strain of $T$. phagedenis was inhibited by 1 unit $/ \mathrm{ml}$. penicillin $G$, while a bactericidal concentration was 100 to 500 units $/ \mathrm{ml}$; and $T$. refringens was inhibited by $0.1 \mathrm{unit} / \mathrm{ml}$., while the bactericidal concentration was 100 units $/ \mathrm{ml}$. Only with $T$. vincentii were growth inhibitory concentrations the same as the bactericidal levels for all but one of the penicillins. This suggests that the outer envelope of treponemes may be limiting the passage of the penicillins to the muramic acid containing cell wall of the protoplasmic cylinder and that not enough penicillin reaches the cell wall to impair irreversibly the synthesis of the new cell wall. An alternative explanation could be that some cells may produce a weak penicillinase. Treponemes requiring serum were more sensitive to penicillin than those requiring rumen fluid. Most of the other antimicrobial agents were bactericidal at concentrations only ten times greater than the inhibitory concentration except when tested against $T$. vincentii $\mathrm{N}-9$ which was inhibited and killed by the same concentrations in many cases. All treponemes were resistant to cycloserine, polymyxin B sulphate, nitrofurazone, furazolidone, nalidixic acid, methenamine mandelate, lysozyme, lysostaphin, sulphonamides, 5-aminouracil, 5-fluorouracil 5-iodouracil, thallium acetate, azocarmine, indigocarmine, and toluidine blue 0 .

Good agreement was found between our resultsand those of other investigators on the bactericida 9 concentrations of penicillin and erythromycin for $T$ ? vincentii (Hampp and Fitzgerald, 1959). The bactericidal concentration of penicillin to oral treponemes was reported by these authors to be 0.3 units $/ \mathrm{ml}$., but our bactericidal concentrations for oral treponemes were much higher. They reported that 0.008 to $>2$ $\mu \mathrm{g} . / \mathrm{ml}$. erythromycin were bactericidal to oral treponemes, but our results ranged from 0.1 to $1 \mu \mathrm{g} . / \mathrm{ml}$. Erythromycin was both inhibitory and bactericidal at low concentrations, with the exception of the Reiter strain of $T$. phagedenis, which required $0.1 \mu \mathrm{g} . / \mathrm{ml}$. to inhibit growth and $500 \mu \mathrm{g} . / \mathrm{ml}$. to kill. Fitzgerald and Hampp (1952) reported that chlortetracycline was bactericidal to $T$. vincentii at 1.25 to $2.5 \mu \mathrm{g} . / \mathrm{ml}$., and we found that $100 \mu \mathrm{g} . / \mathrm{ml}$. were required.

Erythromycin, cephalothin, and tetracyclines are bactericidal to serum requiring treponemes in lower concentrations than those of the penicillins.

Neither spontaneous nor induced mutants resistant to penicillin $G$ or ampicillin were isolated with the Reiter strain of $T$. phagedenis with the techniques that were used. However, this does not imply that resistant mutants cannot be isolated from other treponemes and with other techniques.

The sensitivity of $T$. pallidum to antibiotics in vitro has most often been determined by inhibition of motility of the organism in the presence of the antibiotic. However, there is no cell division of the organism in this test system and most antibiotics are 
considered active only on growing bacterial cells. Even the rapid automated antibiotic sensitivity tests recently developed require at least one cell division to take place. For example, the penicillins inhibit synthesis of new cell wall in an organism that is actively multiplying. The antibiotic sensitivity of $T$. pallidum would be most reliably tested with an actively growing culture of the organism but because $T$. pallidum has not been cultured in vitro, a cultivable treponeme might be used as a model for determination of antibiotic sensitivities in vitro. It is fortunate that the strains of treponemes used in this study were all very similar in their overall pattern of sensitivity and resistance to the antibiotics tested. We suggest that the Nichols strain of T. refringens would be a suitable model strain.

\section{Summary}

The bactericidal concentrations of fifty antimicrobial agents were determined for seventeen strains of treponemes representing most of the known species and several unidentified isolates from pig faeces and the human mouth.

None of the antimicrobial agents studied was bactericidal to every treponemal strain. Most strains were sensitive to cephalothin, vancomycin, bacitracin, erythromycin, tylosin, lincomycin, and tetracycline. Two of the three strains tested were sensitive to gentamicin.

Most strains were resistant to the penicillins, chlortetracycline, chloramphenicol, streptomycin, dihydrostreptomycin, kanamycin, neomycin, viomycin, tyrothricin, usnic acid, potassium tellurite, brilliant green, and crystal violet. Approximately 50 per cent. of the isolates were resistant to novobiocin.

All treponemes were resistant to cycloserine, polymyxin $B$ sulphate, nitrofurazone, furazolidone, nalidixic acid, methenamine mandelate, lysozyme, lysostaphin, sulphonamides, uracil analogs, thallium acetate, azocarmine, indigocarmine, and toluidine blue 0 .

Neither spontaneous nor induced penicillin or ampicillin resistant mutants of the Reiter strain of $T$. phagedenis were isolated.
This investigation was supported, in part, by the National Institutes of Health, Division of General Medical Sciences, Grant GM-14504.

\section{References}

Abramson, I. J., and Smibert, R. M. (1971) Brit. F. vener. Dis., 47, 407

ANAEROBE LABORATORY (1970) Outline of Clinical Methods in Anzerobic Bacteriology, 2nd ed., Virginia Polytechnic Institute and State University, Blacksburg, Virginia 24060. U.S.A.

DEMEREC, M. (1948) F. Bact., 56, 63

EAgle, H., and Musselman, A. D. (1944) f. exp. Med., 80, 493

,-- , and Fleischman, R. (1948) f. Bact., 55, 347

FitzGERALD, R. J., and HAMPP, E. G. (1952) F. dent. Res., 31, 20

Hampp, E. G., and Fitzgerald, R. J. (1959) Ibid., 38, 947

LURIA, S. E., and DeLbRÜCK, M. (1943) Genetics, 28, 491

Activité bactéricide des agents antimicrobiens sur les tréponèmes

SOMMAIRE

On détermina les concentrations bactericides de 50 agents antimicrobiens sur 17 souches de tréponèmes, représentant la plupart des espèces connues, ainsi que sur plusieurs souches non identifiées isolées des fèces du porc et de la bouche de l'homme.

Aucun des agents étudiés ne se montra bactéricide pour toutes les souches de tréponèmes. La plupart des souches furent sensibles à cépiralotine, vancomycine, bacitracine, érythromycine, tylosine, lincomycine et tétracycline. Deux des 3 souches examinées furent sensibles à la gentamicine.

La majorité des souches furent resistantes à pénicillines, chlortétracycline, chloramphénicol, streptomycine, dishydrostreptomycine, kanamycine, néomycine, viomycine, tyrothricine, acide usnique, tellurite postassique, vert brillant et cristal violet. Approximativement, 50 pour cent des souches isolées furent résistantes à la novobiocine.

Tous les tréponèmes furent résistant à cyclosérine, sulfate de polymyxin $B$, nitrofurazone, furazolidone, acide nalidixique, mandelate de méthamine, lysostaphine, sulfonamides, analogues de l'uracil, acétate de thallium, indigocarmine et bleu de toluidine $O$.

Il ne fut isolé aucune souche Reiter de $T$. phagedenis résistante à la pénicilline ou à l'ampicilline, soit à titre spontané, soit à titre de mutants. 